\title{
Urothelial (Transitional Cell) Carcinoma of the Prostate Pathologic Primary Tumor TNM Finding v7
}

National Cancer Institute

\section{Source}

National Cancer Institute. Urothelial (Transitional Cell) Carcinoma of the Prostate

Pathologic Primary Tumor TNM Finding v7. NCI Thesaurus. Code C89378.

A pathologic finding about one or more characteristics of urothelial (transitional cell) carcinoma of the prostate, following the rules of the TNM AJCC V7 classification system as they pertain to staging of the primary tumor. 